\title{
Lenin as an Original Political Theorist, or Not: Debunking the Textbook Interpretation
}

\author{
Jason Schulman ${ }^{*}$
}

Lars T. Lih's Lenin Rediscovered: "What Is to Be Done?" in Context, containing new translations of heretofore mangled Russian terms, proves that Lenin was not initially an authoritarian. It elucidates why What Is To Be Done? is more democratic than popularly believed, but The State and Revolution - not analyzed by Lih - is, ironically, less democratic, given its technocratic picture of "the dictatorship of the proletariat," an outgrowth of Marx's class-reductionist definition of politics and Engels' vision of communism as the "administration of things." This essay reveals what Lenin owed to Kautsky's democratic Marxism and critiques Lukács' theoretical justification for "Leninism." [Article copies available for a fee from The Transformative Studies Institute. E-mail address: journal@transformativestudies.org Website: http://www.transformativestudies.org (02019 by The Transformative Studies Institute. All rights reserved.]

KEYWORDS: Lenin, Marx, Lukács, Socialism, Communism, Democracy.

\section{DEBUNKING THE “TEXTBOOK INTERPRETATION"}

Lenin Rediscovered: "What Is To Be Done" in Context ${ }^{1}$ by independent scholar Lars T. Lih has become a topic of considerable discussion among scholars of Marxism and revolutionary Russia because of its forthright challenge to the traditional interpretation of Lenin's political thought, an interpretation shared across the political spectrum from conservatives to much of the democratic left. This well-known "textbook interpretation," to use Lih's phrase, is that via the publication of What Is To Be Done? (hereafter WITBD?) in 1902 and the 1904 split in the Russian SocialDemocratic Labor Party (RDSLP) Lenin and his "Bolsheviks" (the 1904

\footnotetext{
* Jason Schulman, Ph.D., CUNY Graduate Center (2009), is an adjunct Assistant Professor in the Department of Political Science, Lehman College, City University of New York. Address correspondence to: Jason Schulman, Lehman College, 250 Bedford Park Boulevard West, Bronx, NY 10468-1589; e-mail: jason.schulman@1ehman.cuny.edu.
} 